\title{
Riboflavin Recovery of Spermatogenic Dysfunction via a Dual Inhibition of Oxidative Changes and Regulation of the PINK1- Mediated Pathway in Arsenic-Injured Rat Model
}

\author{
Ali OLFATI ${ }^{1}$, Eva TVRDA ${ }^{2}$ \\ ${ }^{1}$ Young Researchers and Elites Club, Kermanshah Branch, Islamic Azad University, Kermanshah, \\ Iran, ${ }^{2}$ Department of Animal Physiology, Slovak University of Agriculture, Nitra, Slovakia
}

Received February 14, 2021

Accepted May 6, 2021

Epub Ahead of Print June 2, 2021

\section{Summary}

Arsenic trioxide $\left(\mathrm{As}_{2} \mathrm{O}_{3}\right)$ poisoning and associated potential lesions are of a global concern. Inversely, riboflavin (vitamin B2) as a component of flavoproteins could play a vital role in the spermatogenic enzymatic reactions. Thus, this research aimed to explore potential beneficial roles of vitamin $\mathrm{B} 2$ during $\mathrm{As}_{2} \mathrm{O}_{3}$ injured-toxicity. Rats were randomly allocated into 4 groups ( $n=8 /$ group) and challenged as follows (for 30 days continuously): Group 1 received normal saline, Group 2 was treated with $3 \mathrm{mg} / \mathrm{l} \mathrm{As} \mathrm{O}_{3}$, Group 3 received $40 \mathrm{mg} / \mathrm{l}$ vitamin $\mathrm{B} 2$, Group 4 received $3 \mathrm{mg} / \mathrm{l} \mathrm{As} \mathrm{O}_{3}+40 \mathrm{mg} / \mathrm{l}$ vitamin $\mathrm{B} 2$. Both $\mathrm{As}_{2} \mathrm{O}_{3}$ and vitamin B2 were dissolved in deionized water. Malondialdehyde (MDA), Glutathione Peroxidase (GSH-Px), Superoxide dismutase (SOD), and Catalase (CAT) were assessed for the oxidative profile, while TAS (Total Antioxidative Status) levels were evaluated for the antioxidant system, in both serum and testicular tissue. $\mathrm{P}<0.05$ was considered statistically significant. The results show that $\mathrm{As}_{2} \mathrm{O}_{3}$ significantly decreased the body weight, testicular weight and testis volume, semen quality and testicular cell count $(p<0.05)$. Furthermore, MDA content in the testicular tissue of the $\mathrm{As}_{2} \mathrm{O}_{3}$ group rats was significantly higher in comparison to the vehicle group $(p<0.05)$. Likewise, TAS and the activities of GSH-Px, CAT and SOD were reduced $(p<0.05)$ when compared to the control. $\mathrm{As}_{2} \mathrm{O}_{3}$ induced testicular damage and seminiferous tubular atrophy. Monodansylcadaverine assays mirrored the histopathology observations. Meanwhile, $\mathrm{As}_{2} \mathrm{O}_{3}$ upregulated the expression of mitophagy-related genes including PINK1, Parkin, USP8, LC3-I, Fis1 and Mfn2. The p38 gene, responsible to stress stimuli, was also upregulated by $\mathrm{As}_{2} \mathrm{O}_{3}$ administration. Meanwhile, exposure to Vitamin B2 led to a significant decrease of the expression levels of mitophagy related genes. Our study revealed that vitamin B2 supplementation protected testicular structures against $\mathrm{As}_{2} \mathrm{O}_{3}$-induced injury via a dual inhibition of oxidative changes and a regulation of the PINK1-mediated pathway.

\section{Key words}

Oxidative stress - Arsenic trioxide - p38 - PINK1 pathway • Riboflavin • Spermatogenesis

\section{Corresponding author}

Ali Olfati, Young Researchers and Elites Club, Kermanshah Branch, Islamic Azad University, Kermanshah, 6715838588, Iran. Email: A.Olfati65@gmail.com

\section{Introduction}

Arsenic trioxide $\left(\mathrm{As}_{2} \mathrm{O}_{3}\right)$ is a common environmental contaminant that is widely distributed in Pakistan, China, India, Bangladesh, and other Asian countries (Zheng et al. 2017). In the substance priority list revised and published by the Agency for Toxic Substances and Disease Registry 2019, $\mathrm{As}_{2} \mathrm{O}_{3}$ occupies the $1^{\text {st }}$ rank in terms of its toxicity (https://www.atsdr.cdc.gov/spl/\#2019spl). Hence, there is an increasing interest in this chemical, due to its associations with an ever-increasing rise of health issues in industrialized countries as well as its globalized effects. The traditional $\mathrm{As}_{2} \mathrm{O}_{3}$ solution has numerous side effects, such as hyperleukocytosis, liver and kidney dysfunction, as well as effusion (Unnikrishnan et al. 2004). 
The world's population continues to grow older rapidly, mostly because of two reasons: an overall fertility decline, and an increasing worldwide longevity (Barbier et al. 2010). Meanwhile, health sciences have been facing major challenges in the management of reproductive disorders. As reported, $\mathrm{As}_{2} \mathrm{O}_{3}$ administration has led to a variety of impaired organ functions, particularly in the case of the male reproductive system (Souza et al. 2016). Current evidence indicates that exposure to $\mathrm{As}_{2} \mathrm{O}_{3}$ decreases the number, viability, and motility of spermatozoa (Bourguignon et al. 2017), causes damage to spermatogonia and spermatocytes (Huang et al. 2016), and leads to sperm malformations (da Silva et al. 2017). Besides, $\mathrm{As}_{2} \mathrm{O}_{3}$ toxicity may be accompanied with a decreased secretion of gonadotropins, testosterone synthesis and an impaired steroidogenesis that could further affect a proper spermatogenic process (Chiou et al. 2008, Alamda et al. 2017).

Mitochondria are a fundamental source of adenosine triphosphate for cellular health and function, but when damaged, they may generate a plethora of stress signals, which may result in cellular dysfunction and ultimately programmed cell death (Saha et al. 2019). Thus, a major component of maintaining cellular homeostasis lies in the recognition and removal of aberrant mitochondria through autophagy-mediated degradation, i.e., mitophagy (Hamacher-Brady and Brady 2016). Mitophagy, the selective autophagic elimination of dysfunctional mitochondria, is necessary for the maintenance of mitochondrial health and is predominantly regulated by the PINK1-mediated pathway (Koentjoro et al. 2017). Currently, there is no definite evidence if and/or how $\mathrm{As}_{2} \mathrm{O}_{3}$ could induce mitophagy in male reproductive organs.

Despite the food sources of riboflavin or vitamin B2 (as an effective antioxidant in the nutrition) are wellknown (e.g., milk, breads, fortified cereals), only a few nutritional studies have been published to elucidate potential effects of vitamin $\mathrm{B} 2$ on the recovery of spermatogenesis. Vitamin B2 serves as a critical coenzyme for an array of dehydrogenases and oxidases responsible for a normal cell growth and function (Mantheya et al. 2006). A previous study has revealed that vitamin B2 exhibits anti-inflammatory and anti-stress activities in eukaryotic cells (Rivlin 2001). As reported earlier, B vitamin family has been used as a therapeutic agent for the treatment of male infertility and maintenance of a normal sperm function (Beltrame and
Sasso-Cerri 2017). However, little is known about the effects of vitamin B2 in the recovery of spermatogenesis.

Thus, our study examined the hypothesis that vitamin $\mathrm{B} 2$ could protect the testicular structures affected by $\mathrm{As}_{2} \mathrm{O}_{3}$ toxicity via a dual inhibition oxidative changes and regulation of the expression of mitophagy-related genes.

\section{Materials and methods}

\section{Chemicals and ethics}

Unless otherwise indicated, all reagents were obtained from Merck (Darmstadt, Germany). The kits to evaluate reactive oxygen species (ROS), and selected oxidative stress markers (including Total Antioxidative Status (TAS)), malondialdehyde (MDA), glutathione peroxidase (GSH), superoxide dismutase (SOD), and catalase (CAT)) were purchased from Nanjing Jiancheng Bioengineering Institute (China). The Animal Care and Use Committee of the Islamic Azad University Kermanshah approved all experimental procedures of the study that were performed according to international guidelines (IAUK.REC.98-02-32-52385).

\section{Animal selection}

Male adult Wistar rats (weighing 215-225 g, 8-weeks-old) obtained from the Razi Vaccine and Serum Research Institute of Iran (Tehran, Iran) were housed under temperature and light-controlled conditions. Body weight as well as food and water consumption per animal were recorded weekly. No significant differences were found in these measurements between animals in any of the experimental groups during the course of the experiment.

\section{Experimental design}

Rats were randomly allocated into 4 groups ( $n=8$ /group). The animals were challenged as follows (for 30 days continuously): Group 1 received normal saline, Group 2 was treated with $3 \mathrm{mg} / \mathrm{l} \mathrm{As}_{2} \mathrm{O}_{3}$, Group 3 received $40 \mathrm{mg} / \mathrm{l}$ vitamin $\mathrm{B} 2$, Group 4 received $3 \mathrm{mg} / \mathrm{l} \mathrm{As}_{2} \mathrm{O}_{3}+$ $40 \mathrm{mg} / \mathrm{l}$ vitamin $\mathrm{B} 2 . \mathrm{As}_{2} \mathrm{O}_{3}$ and vitamin $\mathrm{B} 2$ were dissolved in deionized water. Daily doses of $\mathrm{As}_{2} \mathrm{O}_{3}$ and vitamin B2 were gradually and slowly dissolved in deionized water for $5 \mathrm{~min}$. $24 \mathrm{~h}$ after the last treatment, the animals were euthanized by anesthesia with $20 \mathrm{mg} / \mathrm{kg}$ ketamine and $0.64 \mathrm{mg} / \mathrm{kg}$ xylazine (Alfasan, Woerden, the Netherlands) and weighed.

The testes were processed for: weigh and 
volume, semen quality, oxidative stress indices including TAS, MDA, GSH-Px, CAT and SOD, histopathology and mRNA expression levels of mitophagy related genes (Fig. 1). Right testes were removed quickly, frozen in liquid nitrogen and stored at $-80{ }^{\circ} \mathrm{C}$ for total RNA extraction. One part of the left testis was fixed in Bouin's solution for histopathological experiments. The other part was kept for electron microscopy observations.

\section{Testis measurements}

The testis weight and volume were measured based on the protocol described in our previous study (Olfati et al. 2019). The absolute total volume $\left(V_{\text {ref }}\right)$ of each testis was measured by the following formula (Howard and Reed 2005):

$$
\begin{aligned}
& V=t(a / p) \sum P \\
& t=\text { mean interval distance between slices. } \\
& a / p=\text { area/test points ratio. } \\
& \sum P=\text { total number of points counted in the slice. }
\end{aligned}
$$

\section{Sperm analysis}

Following removal, left epididymides were cut into 3-4 pieces, and dipped into a cell-culture dish containing $1 \mathrm{ml}$ normal saline solution preheated to $37{ }^{\circ} \mathrm{C}$ and incubated for a few minutes $\left(5 \% \mathrm{CO}_{2}\right)$ in order to allow sperm to swim out the epididymal tubules. An aliquot of sperm suspension was diluted 1:20 with the Ham's F10 medium and transferred into a Neubauer's hemocytometer. Spermatozoa were counted under a light microscope at $\times 400$ and expressed as million $/ \mathrm{ml}$ of suspension (World Health Organization, Department of Reproductive Health and Research, 2010). Sperm motility was determined by placing a drop of $10 \mu \mathrm{l}$ of the sperm suspension into a $37^{\circ} \mathrm{C}$ pre-warmed slide and covered with a coverslip. At least 10 fields were assessed for each sample using a bright-field microscope with a closed diaphragm and the percentage of motile spermatozoa was estimated subjectively (Sakhaee et al. 2012, Tabarraei et al. 2019). Sperm viability was analyzed by the eosinnigrosin staining in 500 spermatozoa. A drop of stained sperm suspension was put on a clean slide and a thin smear was made and allowed for drying. This slide was examined under a light microscope at $\times 1000$ and spermatozoa with white and pink heads were considered as alive or dead, respectively (Olfati et al. 2018).

\section{Histopathological procedures}

The collected testicular tissue was fixed in Bouin's solution for $24 \mathrm{~h}$, and subsequently dehydrated in a series of graded ethanol. A different portion of the tissue was fixed in $10 \%$ buffered neutral formaldehyde for $72 \mathrm{~h}$, cut into $5 \mu \mathrm{m}$ sections by the Leica slicer (Leica, Inc., Germany), stained with the hematoxylin and eosin kit (H\&E) according to the manufacturer's instructions and examined by light microscopy (Olympus, Tokyo, Japan, BX60).

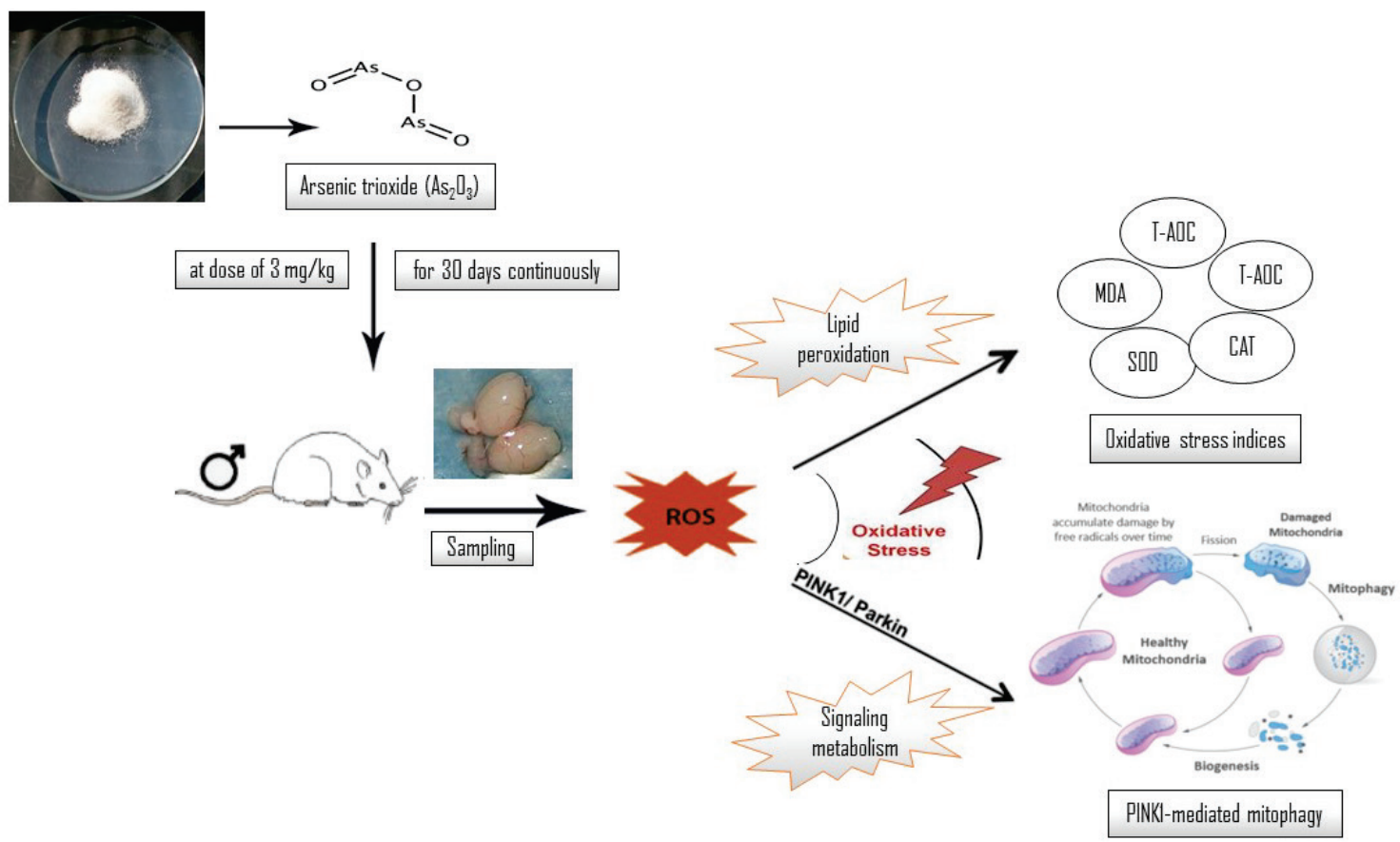

Fig. 1. Experimental design. Healthy rats were treated with $\mathrm{As}_{2} \mathrm{O}_{3}(3 \mathrm{mg} / \mathrm{kg})$ and $40 \mathrm{mg} / \mathrm{l}$ vitamin $\mathrm{B} 2$ daily for 30 days continuously. Following treatment, testicular structure and function were evaluated with a special focus on the dual mitophagy pathway and oxidative stress markers. 


\section{Number of germinal cells}

The relative number of the cells was estimated by the optical dissector principle (Mayhew and Gundersen, 1996). Dissectors were generated as successive focal planes inside a thick section of the testicular tissue. A high numerical aperture oil immersion lens was applied. Five thick (in $\mu \mathrm{m}$ ) visual fields from each paraffin block per each group were analyzed histologically to evaluate the tissue architecture. Twenty to 25 thick (in $\mu \mathrm{m}$ ) visual fields were selected from each block for the counting of the spermatogenic cells (spermatogonia, spermatocytes and spermatids), Sertoli and Leydig cells. The counts were carried out by a cell counter in $\mathrm{x}$ fields.

The number of cells was counted assuming their nuclei as the counting unit. Only the cells within the unbiased counting dissector frame and satisfying the Sterio rule were counted. Finally, the number of the cells was estimated using the optical dissector method and following the provided formula (Kaplan et al. 2012):

$$
N_{v(\text { ell/ref })}:=\sum \sum^{\sum A \times h}
$$

\section{Determination of oxidative stress markers}

The method used to evaluate the oxidative stress level in this experiment was performed as previously described by Jiang et al. (2019). Briefly, the ROS level was assessed using a fluorescence spectrophotometer (NanoDrop 2000, Thermo Fisher Scientific, Waltham, MA, USA) and 2,7-dichlorofluorescin dictate using assay kits and based on the manufacturer's instructions. Appropriate amounts of the right testis $(200 \mathrm{mg})$ were pre-incubated $(70 \mathrm{~min})$ with DCFH-DA $(10 \mu \mathrm{M})$ at $37^{\circ} \mathrm{C}$ to allow for the DCFH-DA to be incorporated into all membrane-bound vesicles. The conversion of DCFH ( $\lambda$ excitation $=485 \mathrm{~nm}$ ) to DCF (green fluorescence, $\lambda$ emission $=525 \mathrm{~nm}$ ) was evaluated using a fluorescence spectrophotometer. The levels of MDA, TAS, GSH-Px, the enzymatic activities SOD, and reduced CAT were measured using commercial kits. Absorbance of each parameter was monitored at 532, 520, 420, 550 and $405 \mathrm{~nm}$, respectively.

\section{MDC staining for the detection of autophagic vacuoles}

Autophagy was evaluated by the monodansylcadaverine (MDC) staining. Left testes were stored in $4 \%$ paraformaldehyde, sectioned, dehydrated and cleared in dimethyl-benzene (xylene), dehydrated in graded ethanol solutions and allowed to air dry completely in the laboratory. Subsequently, the samples were stained with $50 \mathrm{mM} / 1 \mathrm{MDC}$ dye for $45 \mathrm{~min}$ at $37{ }^{\circ} \mathrm{C}$ in the dark. The stained samples were washed with phosphatebuffered saline 5 times ( 5 min each) in the dark, and then allowed to dry at laboratory temperature. HistoChoice ${ }^{\circledR}$ clearing agent was used to inhibit fading of the fluorescence in the darkness. Finally, the optical intensity of the autophagic vacuoles was examined under a fluorescent microscope (Olympus, Tokyo, Japan, BX60).

\section{QPCR method}

Total RNA was isolated from right testis weighing 25-30 mg using the Trizol reagent (Life Technologies, Carlsbad, CA, USA). Two \% agarose gel electrophoresis was used to assess the integrity of total RNA and the A260/280 ratio in the range of 1.8-2.0 was evaluated by NanoDrop 2000 (Thermo Fisher Scientific, Waltham, MA, USA). RNA was reverse transcribed using the PrimeScript ${ }^{\mathrm{TM}}$ RT Master Mix kit (PINK1, Parkin, USP8, USP30, LC3-I, Rab7, Fis1, Mfn2, and p38). QRT-PCR was carried out using the QuantStudio 7 Flex qRT-PCR system (Stratagene, USA) and SYBR ${ }^{\circledR}$ Premix Ex Taq ${ }^{\mathrm{TM}}$ II kit. Specific primers were designed by Invitrogen, USA (Table 1). $\beta$-actin (reference gene) was used to normalize the expression level of target genes. Duplicated $\mathrm{Ct}$ values were measured for each sample, and the comparative $\mathrm{Ct}$ method was used to determine the relative expression level of the target genes (McBride and Coward 2016).

\section{Statistical analysis}

Statistical analysis was performed using the SPSS 13.0 software. The data were processed with oneway analysis of variance (ANOVA) followed by Dunnett's new multiple range test. Values of $p<0.05$ were considered as statistically significant. The results are shown as mean \pm SEM, unless indicated otherwise.

\section{Results}

Results presented in Table 2 reveal a significant decrease in the body weight, testis weight, and testis volume in $\mathrm{As}_{2} \mathrm{O}_{3}$-treated animals $(\mathrm{p}<0.05)$ when compared to the control group. These parameters were preserved in case of vitamin B2 administration (Table $2, \mathrm{p}<0.05$ ).

In comparison to the control group, $\mathrm{As}_{2} \mathrm{O}_{3}$-injured animals exhibited a significantly lower semen quality (including the sperm number, viability and motility, $\mathrm{p}<0.05$ ). Concurrently, exposure to vitamin B2 led to a significant increase in the spermatogenic rate (Table $3, \mathrm{p}<0.05$ ). 
Table 1. Primers used for QRT-PCR: sequence and product size

\begin{tabular}{|c|c|c|c|}
\hline Target gene & Gene Bank accession no. & PCR fragment length (bp) & Sequences $\left(5^{\prime}-3^{\prime}\right)$ \\
\hline PINK1 & NM_026880.2 & 172 & $\begin{array}{l}\text { Forward: ctgcagatgctgtttctggc } \\
\text { Reverse: agccaccttcttcagccttc }\end{array}$ \\
\hline Parkin & NM_001317726.1 & 177 & $\begin{array}{l}\text { Forward: cctgcaaacaagcaaccetc } \\
\text { Reverse: tcaaagctaccgacgtgtcc }\end{array}$ \\
\hline USP8 & NM 001252580.1 & 167 & $\begin{array}{l}\text { Forward: agagaacaacgagcacctgg } \\
\text { Reverse: acatgaaggcctcgaaggtg }\end{array}$ \\
\hline USP30 & NM_001033202.3 & 224 & $\begin{array}{l}\text { Forward: agctgtgtcatctgcacctc } \\
\text { Reverse: ttgctccacttctgctcagg }\end{array}$ \\
\hline$L C 3-I$ & NM_025735.3 & 196 & $\begin{array}{l}\text { Forward: atcatcgagcgctacaaggg } \\
\text { Reverse: agatgtcagcgatgggtgtg }\end{array}$ \\
\hline Rab7 & NM_001364358.1 & 203 & $\begin{array}{l}\text { Forward: tttgccctaagcaggtctgg } \\
\text { Reverse: agaaacagctctccagtcgc }\end{array}$ \\
\hline Fis1 & NM_001163243.1 & 245 & $\begin{array}{l}\text { Forward: agaacaaccaggccaaggag } \\
\text { Reverse: aaagggaaggcgatggtgag }\end{array}$ \\
\hline Mfn 2 & NM_001285920.1 & 186 & $\begin{array}{l}\text { Forward: aacaaggactggacagctcg } \\
\text { Reverse: tgtgctcaggctggagaaag }\end{array}$ \\
\hline p38 & NM 001168508.1 & 231 & $\begin{array}{l}\text { Forward: tgtgtttgcatgctgtgctc } \\
\text { Reverse: agatggcaagggttcaggtg }\end{array}$ \\
\hline
\end{tabular}

Table 2. Effect of riboflavin on the body weight, testicular weight, and testicular volume in an arsenic-injured rat model

\begin{tabular}{lccc}
\hline Groups (n=8) & Body weight $(\mathbf{g})$ & Testis weight $(\mathbf{g})$ & Testis volume $^{\left(\mathbf{c m}^{3}\right)}$ \\
\hline Vehicle & $258.75 \pm 8.65^{\mathrm{a}}$ & $1.51 \pm 0.072^{\mathrm{a}}$ & $1.41 \pm 0.03^{\mathrm{a}}$ \\
$\mathrm{As} \mathrm{O}_{3} 3 \mathrm{mg} / \mathrm{kg}$ & $196.00 \pm 3.17^{\mathrm{b}}$ & $0.92 \pm 0.192^{\mathrm{b}}$ & $0.66 \pm 0.10^{\mathrm{b}}$ \\
itamin B2 $40 \mathrm{mg} / \mathrm{kg}^{\mathrm{b}}$ & $255.00 \pm 4.38^{\mathrm{a}}$ & $1.46 \pm 0.042^{\mathrm{a}}$ & $1.39 \pm 0.19^{\mathrm{a}}$ \\
$\mathrm{As}_{2} \mathrm{O}_{3}+$ vitamin B2 & $251.50 \pm 5.22^{\mathrm{a}}$ & $1.39 \pm 0.058^{\mathrm{a}}$ & $1.33 \pm 0.03^{\mathrm{a}}$ \\
\hline
\end{tabular}

$\mathrm{As}_{2} \mathrm{O}_{3}$ : arsenic trioxide. Values are given as means \pm S.D. The same superscripts (a-b) are not significantly different from each other in each column $(\mathrm{p}<0.05)$. Total volume $\left(V\right.$ of each testis: $V=t(a / p) \sum P$, where " $t$ " was the mean interval distance between slices, $(a / p)$ represented the area related with each test point and " $\Sigma P^{\prime}$ was the total number of points counted in all slices.

Table 3. The effect of riboflavin on the semen quality in an arsenic-injured rat model

\begin{tabular}{lccc}
\hline Groups (n=8) & Spermatozoa $\left(\times \mathbf{1 0}^{\mathbf{6}}\right)$ & Viability (\%) & Motility (\%) \\
\hline Vehicle & $36.88 \pm 0.69^{\mathrm{a}}$ & $73.26 \pm 0.12^{\mathrm{a}}$ & $72.73 \pm 0.53^{\mathrm{a}}$ \\
$\mathrm{As}_{2} \mathrm{O}_{3} 3 \mathrm{mg} / \mathrm{kg}$ & $19.65 \pm 0.48^{\mathrm{b}}$ & $34.14 \pm 0.56^{\mathrm{b}}$ & $39.30 \pm 0.12^{\mathrm{b}}$ \\
Vitamin B2 $40 \mathrm{mg} / \mathrm{kg}_{\mathrm{As}} \mathrm{O}_{3}+$ vitamin B2 & $39.23 \pm 1.19^{\mathrm{a}}$ & $78.70 \pm 0.92^{\mathrm{a}}$ & $74.25 \pm 0.92^{\mathrm{a}}$ \\
\hline
\end{tabular}

$\mathrm{As}_{2} \mathrm{O}_{3}$ : arsenic trioxide. Values are given as means \pm S.D. The same superscripts (a-b) are not significantly different from each other in each column $(p<0.05)$.

Fig. 2 (sections 1 - 4) shows representative sections of histopathology of the testicular tissue of rats. Control animals exhibited normal histological structures with a regular morphology (sections 1 and 3).
Meanwhile, the administration of $\mathrm{As}_{2} \mathrm{O}_{3}$ caused a widespread damage to the testicular cells and tissues accompanied by a seminiferous tubular atrophy (section 2), presenting with induced seminiferous tubular 


\section{1) Vehicle}

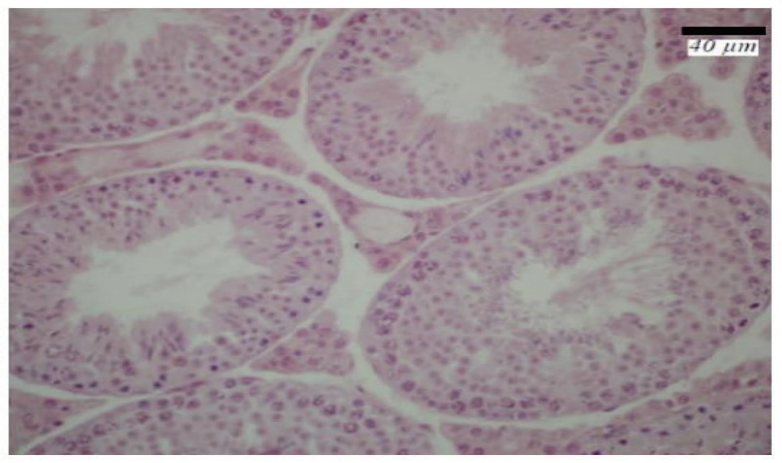

3) Riboflavin $(40 \mathrm{mg} / \mathrm{kg})$

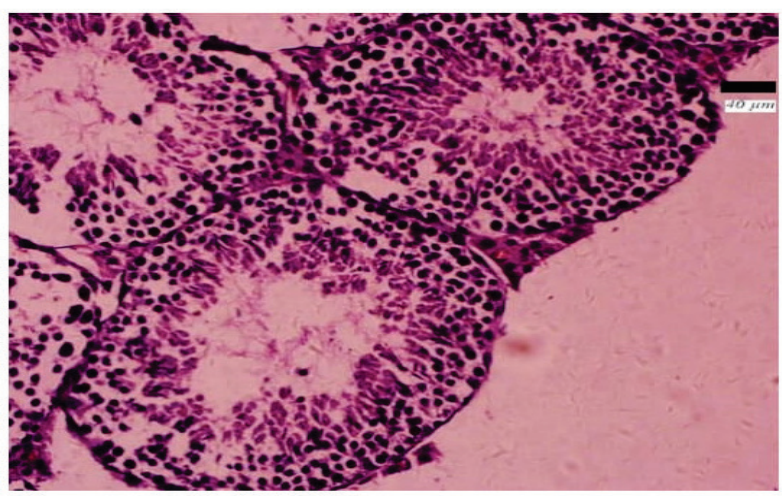

2) Arsenic (3 mg/kg)

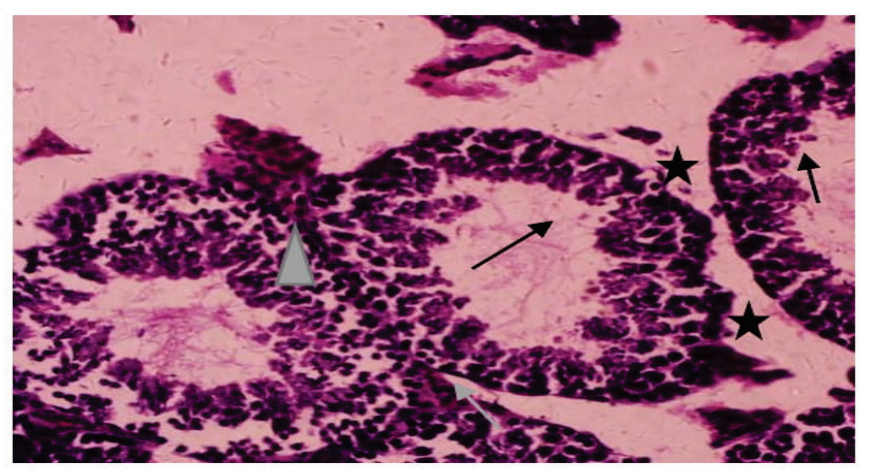

4) Arsenic (3 mg/kg)+Riboflavin (4O mg/kg)

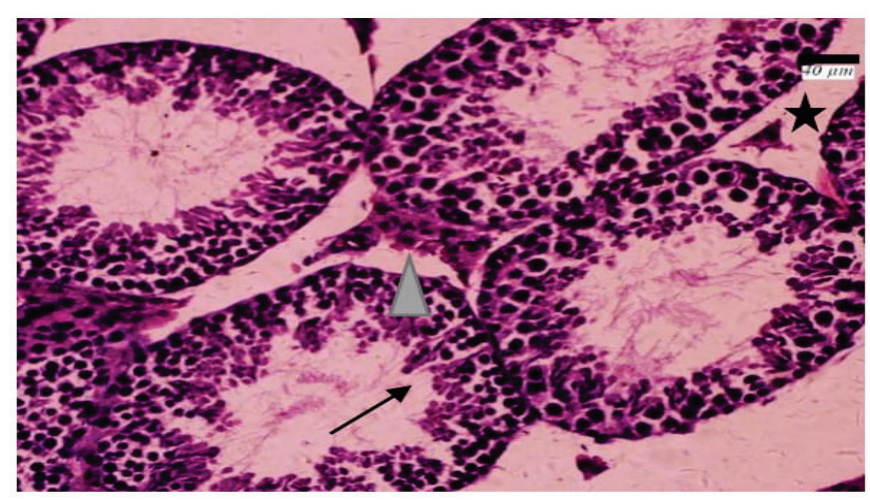

Fig. 2. Histopathological changes in the testicular tissue of rats (H\&E staining). The magnification is $\times 40$. Symbols: black arrows extensive atrophy in the seminiferous tubules and destruction of the germinal epithelium, gray arrows - shrinkage of the basal lamina, asterisks - Increased interstitial space, hallow arrow head - congested blood vessels and vascular hyperemia

Table 4. The effect of riboflavin on the number of spermatogenic cells in an arsenic-injured rat model $\left(\times 10^{8}\right)$

\begin{tabular}{lccccc}
\hline Groups (n=8) & Spermatogonia & Spermatocyte & Spermatid & Sertoli & Leydig \\
\hline Vehicle & $89.80 \pm 2.25^{\text {a }}$ & $124.50 \pm 6.24^{\mathrm{a}}$ & $211.00 \pm 10.29^{\mathrm{a}}$ & $24.20 \pm 3.65$ & $22.59 \pm 2.06^{\mathrm{a}}$ \\
$\mathrm{As} \mathrm{O}_{3} 3 \mathrm{mg} / \mathrm{kg}$ & $55.40 \pm 3.63^{\mathrm{b}}$ & $85.31 \pm 9.82^{\mathrm{b}}$ & $136.44 \pm 7.16^{\mathrm{b}}$ & $19.35 \pm 1.76$ & $14.12 \pm 1.05^{\mathrm{d}}$ \\
itamin $\mathrm{B} 240 \mathrm{mg} / \mathrm{kg}^{\mathrm{b}} \mathrm{As}_{2} \mathrm{O}_{3}+$ vitamin B2 & $90.03 \pm 3.23^{\mathrm{a}}$ & $130.00 \pm 11.22^{\mathrm{a}}$ & $220.80 \pm 8.32^{\mathrm{a}}$ & $24.09 \pm 1.31$ & $23.91 \pm 1.43^{\text {a }}$ \\
\hline
\end{tabular}

$\mathrm{As}_{2} \mathrm{O}_{3}$ : arsenic trioxide. Values are given as means \pm S.D. The same superscripts (a-b) are not significantly different from each other in each column $(p<0.05)$.

Table 5. The effect of riboflavin on the oxidative stress markers in an arsenic-injured rat model

\begin{tabular}{lcccccc}
\hline Groups $(\mathbf{n}=\mathbf{8})$ & ROS $\left(\times \mathbf{1 0}^{\mathbf{5}}\right)$ & TAS & MDA & GSH-Px & SOD & CAT \\
\hline Vehicle & $1.11 \pm 0.55^{\mathrm{b}}$ & $95 \pm 9.04^{\mathrm{a}}$ & $2.3 \pm 0.08^{\mathrm{b}}$ & $755 \pm 38.6^{\mathrm{a}}$ & $28 \pm 2.08^{\mathrm{a}}$ & $255 \pm 18.2^{\mathrm{a}}$ \\
$\mathrm{As}_{2} \mathrm{O}_{3} 3 \mathrm{mg} / \mathrm{kg}$ & $2.09 \pm 0.93^{\mathrm{a}}$ & $41 \pm 5.22^{\mathrm{b}}$ & $11 \pm 1.07^{\mathrm{a}}$ & $330 \pm 28.9^{\mathrm{b}}$ & $12 \pm 1.32^{\mathrm{b}}$ & $131 \pm 11.9^{\mathrm{b}}$ \\
Vitamin B $40 \mathrm{mg} / \mathrm{kg}^{\mathrm{a}} \mathrm{1.01} \pm 0.48^{\mathrm{b}}$ & $98 \pm 8.19^{\mathrm{a}}$ & $2.2 \pm 0.33^{\mathrm{b}}$ & $770 \pm 41.2^{\mathrm{a}}$ & $29 \pm 2.18^{\mathrm{a}}$ & $261 \pm 17.3^{\mathrm{a}}$ \\
$\mathrm{As}_{2} \mathrm{O}_{3}+$ vitamin B2 $^{\mathrm{a}}$ & $1.34 \pm 0.19^{\mathrm{b}}$ & $81 \pm 7.62^{\mathrm{a}}$ & $1.9 \pm 0.11^{\mathrm{b}}$ & $680 \pm 40.1^{\mathrm{a}}$ & $25 \pm 2.02^{\mathrm{a}}$ & $238 \pm 16.7^{\mathrm{a}}$ \\
\hline
\end{tabular}

$\mathrm{As}_{2} \mathrm{O}_{3}$ : arsenic trioxide. Values are given as means \pm S.D. The same superscripts (a-b) are not significantly different from each other in each column $(p<0.05)$. ROS (DCF Fluorescence Intensity): reactive oxygen species; TAS (\% of control): totalantioxidant status; MDA ( $\mathrm{nmol} / \mathrm{mg}$ protein): malondialdehyde; GSH-Px ( $\mu \mathrm{g} / \mathrm{g}$ tissue): glutathione peroxidase, SOD (U/mg protein): superoxide dismutase; CAT ( $\mathrm{mU} / \mathrm{mg}$ protein): catalase 
deformities, an increased interstitial tissue, vascular hyperemia, congested blood vessels and a shrinkage of the basal lamina. On the other hand, vitamin B2 administration enabled the repair (proportionally) of the testicular cells, leading to the occurrence of an organized germinal epithelium (section 4).Table 4 shows that exposure to $\mathrm{As}_{2} \mathrm{O}_{3}$ lead to a significant decrease in the number of testicular cells (all types including spermatogonia, spermatocytes, spermatids, Sertoli and Leydig cells) in comparison to the control $(\mathrm{p}<0.05)$, while a significant increase in the quantity of testicular cells was observed in both vitamin B2 groups $(p<0.05)$, reflecting the histopathological observations.

The assessment of oxidative stress markers (Table 4) reveals significant $(p<0.05)$ changes in their contents in rats exposed to $\mathrm{As}_{2} \mathrm{O}_{3}$ when compared to the control at the end of the experiment. The MDA concentration in the $\mathrm{As}_{2} \mathrm{O}_{3}$ group was significantly higher when compared to the control group $(p<0.05)$. Likewise, our results indicate that the average TAS and the activities of GSH-Px, SOD and CAT were significantly decreased $(\mathrm{p}<0.05)$ in the animals treated with $\mathrm{As}_{2} \mathrm{O}_{3}$. All observed prooxidant changes were reversed by vitamin B2 administration.

According to the fluorescence microscopy, MDC-labeled autophagic vacuoles appeared as distinct, dot-like structures (Fig. 3, sections 1-4). An increase in the amount of MDC-labeled autophagic vacuoles was observed in the group exposed to $\mathrm{As}_{2} \mathrm{O}_{3}$ (sections 2 and 4). All pathological alterations were reversed proportionally by the vitamin B2 treatment (section 4).

mRNA expression levels of mitophagy genes such as PINK1, Parkin, USP8, LC3-I, Rab7, Fis1, Mfn2 and p38 were examined by QRT-PCR (Fig. 4). All mitophagy markers (except of Rab7) were significantly up regulated in the $\mathrm{As}_{2} \mathrm{O}_{3}$ treated groups when

\section{1) Vehicle}

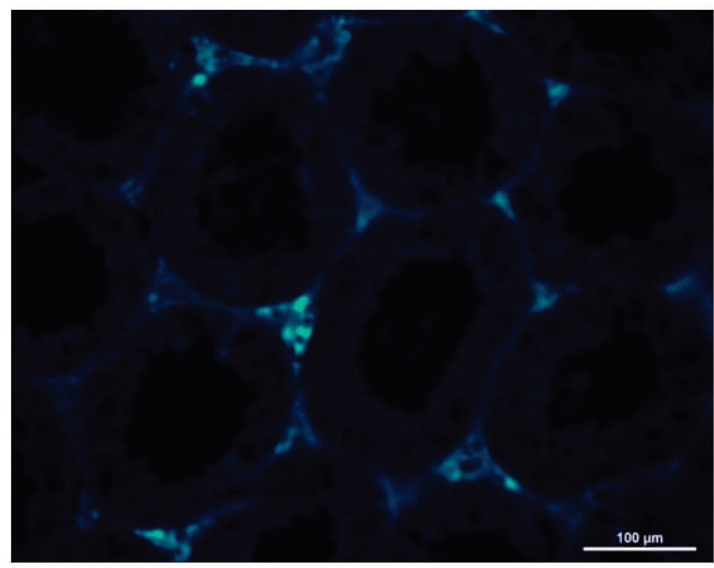

3) Riboflavin (40 mg/kg)

\section{2) Arsenic (3 mg/kg)}

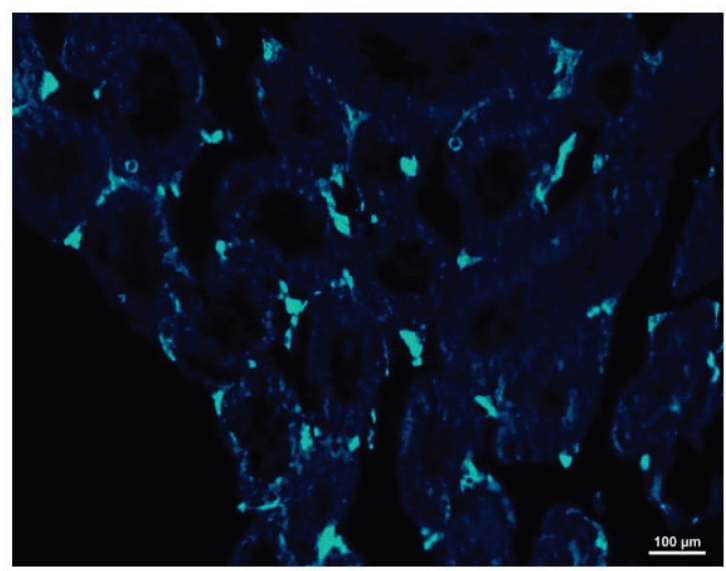

4) Arsenic (3 mg/kg)+Riboflavin $(40 \mathrm{mg} / \mathrm{kg})$

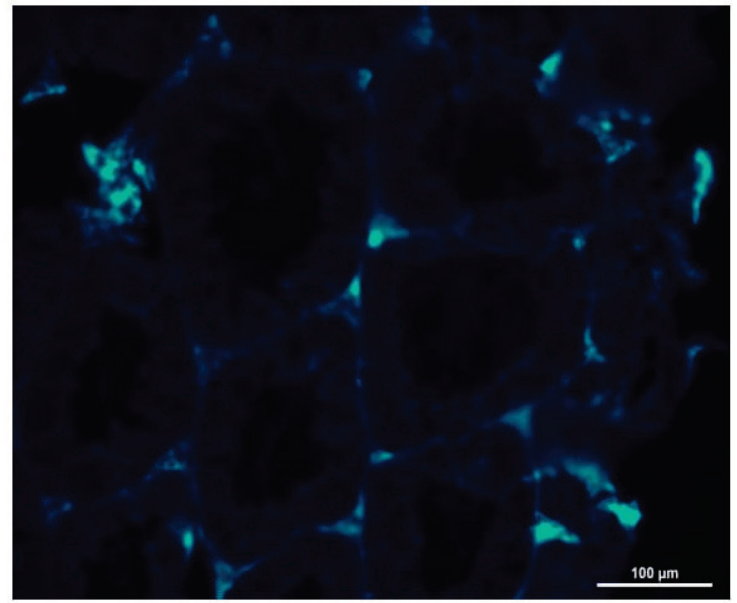

Fig. 3. Qualitive monodansylcadaverine (MDC)-labeled autophagic vacuoles in rat testis. $\mathrm{As}_{2} \mathrm{O}_{3}$-induced autophagy was detectable by autofluorescence emitted by MDC staining (400×magnification, Bar $=10 \mu \mathrm{m})$. 


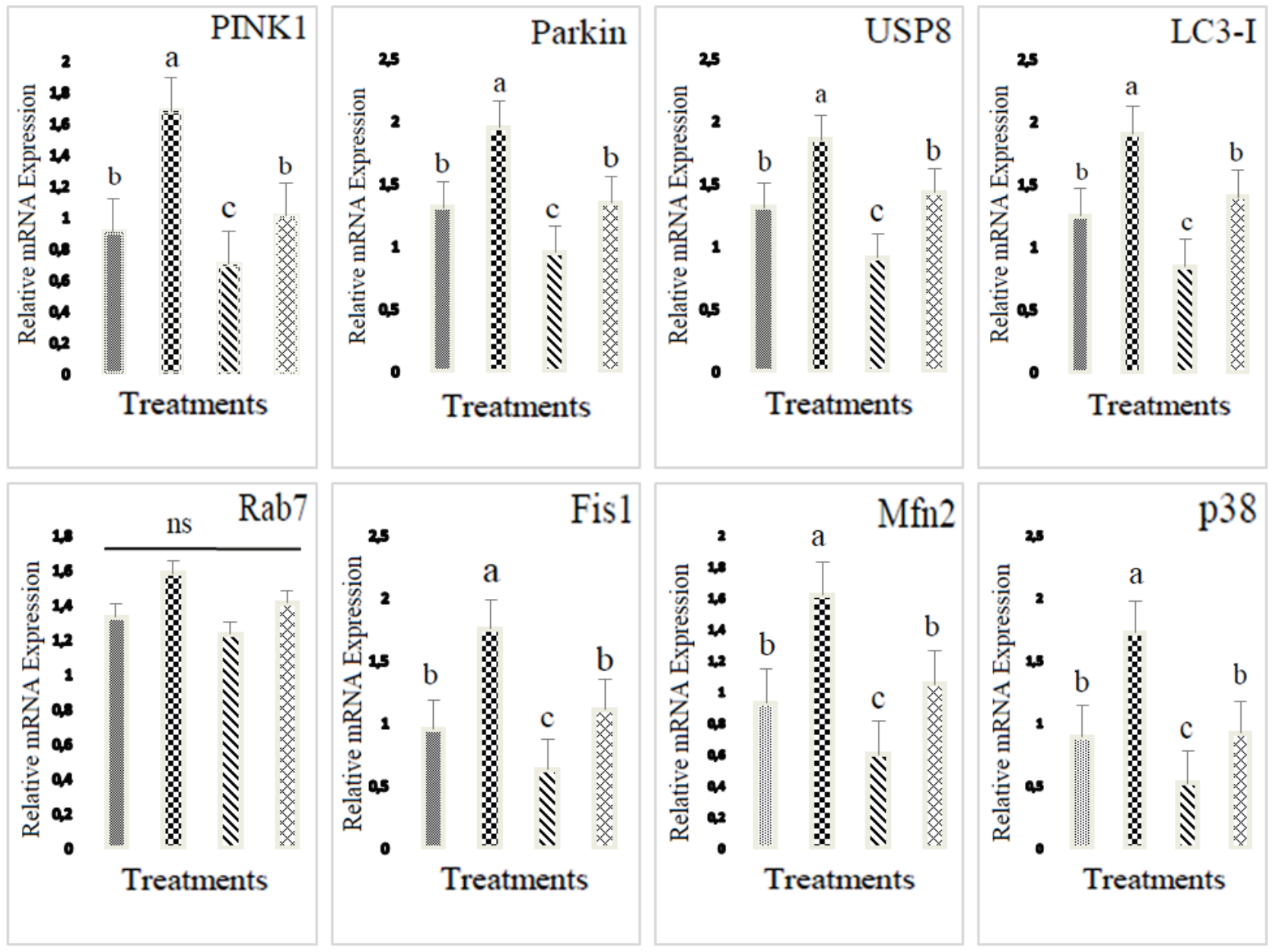

Vehicle

Arsenic $(3 \mathrm{mg} / \mathrm{kg}) \quad \&$

Riboflavin $(40 \mathrm{mg} / \mathrm{kg}$ )

Arsenic + Riboflavin

Fig. 4. Changes in the expressions of mitophagy key markers in mRNA induced by $\mathrm{As}_{2} \mathrm{O}_{3}$, mRNA expressions levels of PINK1, Parkin, USP8, LC3-I, Rab7, Fis1, Mfn2 and p38 as detected by qPCR. All data were expressed as relative values against their respective control group. $\beta$-actin was used as an internal control. The values are presented as mean \pm SEM $(n=5)$. The same superscripts (a-c) are not significantly different from each other $(p<0.05)$.

compared to the control group $(\mathrm{p}<0.05)$. However, $\mathrm{p} 38$ was also upregulated by $\mathrm{As}_{2} \mathrm{O}_{3}$ administration. Meanwhile, exposure to vitamin $\mathrm{B} 2$ led to a significant decrease of the expression levels of mitophagy related genes $(\mathrm{p}<0.05)$.

\section{Discussion}

In the era of a rising environmental contamination, research in andrology needs to be more aware of the potential detrimental effects of environmental pollutants on the spermatogenic process.
As the body of evidence grows in support of restorative therapies for the recovery of spermatogenesis, it is important to be familiar with emerging treatment options, as well as the timeframe of their administration (McBride and Coward 2016). Vitamin supplementation in animal models for the promotion of health has become an increasingly more common scientific approach. As such, this study is the first to report the potential beneficial health effects of vitamin $\mathrm{B} 2$ on $\mathrm{As}_{2} \mathrm{O}_{3}$-exposed rats presenting with a spermatogenic dysfunction, and subsequently explored its possible mechanisms of action.

As observed in this study, $\mathrm{As}_{2} \mathrm{O}_{3}$ significantly 
affected male reproductive cells and tissues (Souza et al. 2016). Specifically, a significantly diminished testicular weight and the quantity of testicular cells were recorded post $\mathrm{As}_{2} \mathrm{O}_{3}$ exposure, partly due to an increased oxidative stress. This phenomenon is in line with earlier reports using mice (Sarkar et al. 2008, Rao et al. 2013) and rat (Huang et al. 2016) models, which have postulated that changes in the testicular weight may occur due to tissuespecific toxicity of $\mathrm{As}_{2} \mathrm{O}_{3}$. It is known that the regulation of the cell number is extremely important for the maintenance of the size, weight and function of tissue and organ structures (Beltrame and Sasso-Cerri, 2017).

Inversely, the semen quality including the sperm count, viability and motility improved in rats administered with vitamin B2. Our results of the semen analysis reveal a rapid recovery with medical therapy (vitamin B2, 30 days continuously) aimed to stimulate the endogenous testicular functions. This fast improvement could be associated with antioxidant properties of vitamin B2 translated into its ability to prevent lipid peroxidation and to protect germ cells from oxidative damage by scavenging free radicals. Lipid peroxidation is an important factor contributing to spermatogenic dysfunction (Hana et al. 2019). Multiple studies have demonstrated that vitamin B2 attenuated lipid peroxidation, proposing that its mechanism of action could lie in flavin adenine dinucleotide (FAD) replenishment (Angelini et al. 2016) or demethylation of key enzymes playing important roles in the phospholipid metabolism (Wang et al. 2018). In addition, similar results were reported from an oral antioxidant study in which treatment with the B vitamin family was found to improve the sperm vitality, motility, and DNA integrity (Abad et al. 2013). Furthermore, systematic reviews suggest positive effects of the B vitamin family on the semen quality: first, by increasing the sperm count, enhancing the sperm motility and reducing sperm DNA damage (Banihani 2017), and second, by stimulating DNA synthesis and thus contributing to the cell division (Oh and Brown 2003).

In this study, typical feature pathological and histological changes (atrophy and deformities) were observed in the testicular morphology of the groups exposed to $\mathrm{As}_{2} \mathrm{O}_{3}$, leading to the assumption that $\mathrm{As}_{2} \mathrm{O}_{3}$ exerts its primary toxicity in the testicular tissue (Fig. 2). Accordingly, latest studies have revealed morphometrical and morphological changes in the testis of laboratory animals caused by chronic $\mathrm{As}_{2} \mathrm{O}_{3}$ administration (Huang et al. 2016, Guvvala et al. 2016, de Araujo
Ramos et al. 2017).

Sub-chronic exposure to $\mathrm{As}_{2} \mathrm{O}_{3}$ is known to be associated with an induced oxidative stress in reproductive structures, which may lead to a decreased spermatogenic efficiency by an increased occurrence of oxidative insults (Huang et al. 2016). Our study showed that $\mathrm{As}_{2} \mathrm{O}_{3}$ promotes excessive generation of ROS, which could disrupt the oxidative milieu in testicular tissues. Subsequently, enzymatic and non-enzymatic antioxidants fail to inhibit the over generation of lipid peroxides, especially MDA (the end-product of lipid peroxidation). In $\mathrm{As}_{2} \mathrm{O}_{3}$ administered groups, the testicular damage was associated with elevated MDA levels. Similarly, previous studies stated that $\mathrm{As}_{2} \mathrm{O}_{3}$ exposure enhanced the MDA production in brain (Sun et al. 2018) and reproductive tissues (Shao et al. 2018) of chicken, which indirectly reflected on the severity of ROS attacks. Moreover, most of the recent studies have claimed that excess ROS will break the oxidative homeostasis, reflected in an increased MDA content, a decreased ability to resist hydroxyl radicals and an inhibition of numerous anti-oxidative enzymatic activities (Reddy et al. 2017, Sun et al. 2018). Lower levels of ROS and MDA in the vitamin B2 group might be responsible for the withdrawal of the inhibitory effects of $\mathrm{As}_{2} \mathrm{O}_{3}$ toxicity on the testicular antioxidant system as well as a diminution of free radical generation. All observed changes in the oxidative markers were proportionally abolished by vitamin $\mathrm{B} 2$ as a candidate therapy.

Autophagy begins with the formation of autophagosomes, which envelop a portion of the cytoplasm and deliver cytoplasmic components to the degradative organelle (lysosome/vacuole) for further breakdown and recycling (Schneider and Cuervo 2014, Marshall and Vierstra 2018). Our experiments suggest that $\mathrm{As}_{2} \mathrm{O}_{3}$ exposure induces the formation of autophagosomes in male reproductive cells or tissues, indicating that $\mathrm{As}_{2} \mathrm{O}_{3}$ could enhance testicular autophagy. $\mathrm{As}_{2} \mathrm{O}_{3}$-associated alterations to the autophagic flux could be considered a form of embodiment of $\mathrm{As}_{2} \mathrm{O}_{3}$-induced toxicity. In addition, the dysregulation of autophagy may occur due to the impact of $\mathrm{As}_{2} \mathrm{O}_{3}$ on the autophagosomallysosomal function. Apart from the de novo formation of autophagosomes, another reason for their accumulation may be associated with the blockage of autophagosomal degradation due to the aggregation of $\mathrm{p} 38$ (the gene responsive to stress stimuli). Inversely, $\mathrm{As}_{2} \mathrm{O}_{3}$-induced testicular cell death was blocked by vitamin B2 as a candidate therapy. In this case, a balance between 
autophagy and cell proliferation might have occurred in the groups supplemented with vitamin B2 since the tissue was kept in homeostasis.

As shown in Figure 3, upon administration of vitamin B2, the diffused distribution of MDC in the cytoplasm was converted to a dot-like appearance. Concurrently, based on the histopathology and MDC results, vitamin B2 could promote the activity of the mitophagy pathway to counteract the stress caused by environmental pollutants and to facilitate the cell proliferation by suppressing stress responses (ROS production) as well as by promoting metabolism and survival. Collectively, our findings indicate that vitamin B2 exposure changes the expression patterns of mitophagy-related genes, which could affect the degradation of autophagosomes. Hence, it is recommended that future experiments should be focused more on the exact relationships among specific signaling pathways involved in the process of mitophagy in the male reproductive system.

Our data revealed that $\mathrm{As}_{2} \mathrm{O}_{3}$ as an extracellular stimulus, could have an impact on the PINK1-mediated pathway in the male reproductive system, which may ultimately act either as a death safeguard. PINK1 protein is known as a sensor of mitochondrial damage and mitophagy (Horibe et al. 2019). In addition, Parkin protein acts in the facilitation of the mitochondrial translocation (Zhoua et al. 2019). In injured animals, increased ROS levels can activate the PINK1-mediated signaling pathway. It has been previously reported that the PINK1/Parkin pathway plays a pivotal role as a mitophagy mediator in mammals (Chen et al. 2013, Eiyama and Okamoto 2015), which is mainly involved in the elimination of damaged mitochondria. Thus, PINK1mediated pathway is important for the regulation in the expression patterns of mitophagy, which is essential to maintain the integrity of testicular cells or tissues.

The results of mRNA expression levels of mitophagy markers reveal that $\mathrm{As}_{2} \mathrm{O}_{3}$ could induce a mitochondrial impairment in the testicular cells or tissues, which may represent one of the potential mechanisms of $\mathrm{As}_{2} \mathrm{O}_{3}$-associated reproductive toxicity. Thus, studies on the expression patterns of mitophagy makers in the male reproductive organs may be advantageous to understand whether exposure to $\mathrm{As}_{2} \mathrm{O}_{3}$ induces a mitophagy response against reproductive toxicity. The present findings suggest that vitamin B2 improved the spermatogenic homeostasis via PINK1mediated pathway. It is known that vitamin B2 is mainly metabolized in the liver and becomes FAD to regulate metabolism (Kumar et al. 2002, Barile et al. 2016). Taken together, these results demonstrate that vitamin B2 exerts a vital protective effect on the spermatogenic dysfunction in a rat model, which could be attributed to its direct protective effects on damaged testis via inhibiting oxidative changes as well as regulating the expression of mitophagy-related genes. Besides, our results reveal a potential involvement of the PINK1mediated signaling pathway in the fate of spermatogenesis, however more evidence is needed to further demonstrate its effects on the testicular function in $\mathrm{As}_{2} \mathrm{O}_{3}$-injured animal or human models.

Latest studies state that the expression levels of p38 probably play an important role in ROS-induced damage to the blood-testis barrier (BTB) (Chen et al. 2018). Our present results reveal a marked downregulated expression of p38 (key kinases for mitochondrial adaptation) (Takahashi et al. 2019) following vitamin B2 administration when compared to the $\mathrm{As}_{2} \mathrm{O}_{3}$ exposed groups. Thus, vitamin $\mathrm{B} 2$, transferred from the blood to the male reproductive organs could inhibit $\mathrm{As}_{2} \mathrm{O}_{3}$-induced disruption of the BTB by regulating oxidative stress-mediated $\mathrm{p} 38$ pathways, which could provide an explanation to the improvement of the spermatogenic dysfunction. While these protective effects of vitamin B2 may be partly contributed by co-treatment with p38 pathways. Further studies focusing on the specific effect of vitamin B2 on the BTB functions would clarify this speculation.

Till now, there was no report available describing the effect of p38 expression patterns on the spermatogenic dysfunction, while our study is the first to reveal a hint that $\mathrm{p} 38$ overexpression could lead to an enhanced testicular mitophagy. Hence, it is recommended that future experiments should focus more on the exact relationships among signaling pathways triggering mitophagy in the male reproductive system.

\section{Conclusions}

In conclusion, the results of the present study indicate a beneficial relationship between vitamin B2 therapy and regeneration of the spermatogenic function. Likewise, the data presented suggest that vitamin B2 therapy could be a potentially effective strategy to modify the detrimental effects of $\mathrm{As}_{2} \mathrm{O}_{3}$ in an animal model by inhibiting oxidative changes and by regulating the PINK1-mediated pathway. It should be noted that 
similarly to previous studies in this era, there are some limitations. In this case, the limitations involve the type and design of the studies in which the cause and effective relationship between the variables cannot be determined since most of these studies are observational and crosssectional. They use different cut off points to determine the normal levels of vitamin B2, as well as other cut off points to test other biomarkers with Western blotting. Also the use of vitamin B2 supplementation was not controlled in the investigations. These limitations build the foundation for interventional studies with adequate samples and follow up periods to clarify the roles of vitamin B2 in PINK1-mediated pathway that could be applied in the prevention and treatment of male reproductive dysfunction in the future.

\section{Conflict of Interest}

There is no conflict of interest.

\section{Acknowledgements}

This study was supported by the APVV 15-0544 and KEGA 008SPU-4/2021 projects. The authors thank Prof. Dr. Mehrdad Payandeh for providing drugs and facilities.

\section{References}

ABAD C, AMENGUAL MJ, GOSALVEZ J, COWARD K, HANNAOUI N, BENET J, GARCIA-PEIRO A, PRATS J: Effects of oral antioxidant treatment upon the dynamics of human sperm DNA fragmentation and subpopulations of sperm with highly degraded DNA. Andrologia 45: 211-216, 2013. https://doi.org/10.1111/and.12003

ALAMDAR A, XI G, HUANG Q, TIAN M, EQANI S, SHEN H: Arsenic activates the expression of 3beta-HSD in mouse Leydig cells through repression of histone H3K9 methylation. Toxicol Appl Pharmacol 326: 7-14, 2017. https://doi.org/10.1016/j.taap.2017.04.012

ANGELINI C, NASCIMBENI AC, CENACCHI G, TASCA E: Lipolysis and lipophagy in lipid storage myopathies, Biochim Biophys Acta 862: 1367-1373, 2016. https://doi.org/10.1016/j.bbadis.2016.04.008

BANIHANI SA: Vitamin B12 and Semen Quality. Biomolecules 7: 42, 2017. https://doi.org/10.3390/biom7020042

BARBIER O, ARREOLA-MENDOZA L, DEL RAZO LM: Molecular mechanisms of fluoride toxicity. Chem Biol Interact 188: 319-333, 2010. https://doi.org/10.1016/j.cbi.2010.07.011

BARILE M, GIANCASPERO TA, LEONE P, GALLUCCIO M, INDIVERI C: Riboflavin transport and metabolism in humans. J Inherit Metab Dis 39: 545-557, 2016. https://doi.org/10.1007/s10545-016-9950-0

BELTRAME FL, SASSO-CERRI E: Vitamin B12-induced spermatogenesis recovery in cimetidine-treated rats: effect on the spermatogonia number and sperm concentration. Asian J Androl 19: 567-572, 2017. https://doi.org/10.4103/1008-682X.182397

BOURGUIGNON NS, BONAVENTURA MM, RODRIGUEZ D, BIZZOZZERO M, VENTURA C, NUNEZ M, LUX-LANTOS VA, LIBERTUN C: Evaluation of sodium arsenite exposure on reproductive competence in pregnant and postlactational dams and their offspring. Reprod Toxicol 69: 1-12, 2017. https://doi.org/10.1016/j.reprotox.2017.01.002

CHEN N, SU P, WANG M, LI YM: Ascorbic acid inhibits cadmium-induced disruption of the blood-testis barrier by regulating oxidative stress-mediated p38 MAPK pathways, Environ Sci Pollut Res Int 25: 21713-21720, 2018. https://doi.org/10.1007/s11356-018-2138-4

CHEN Y, DORN GW: PINK1-phosphorylated mitofusin 2 is a parkin receptor for culling damaged mitochondria. Science 340: 471-475, 2013. https://doi.org/10.1126/science.1231031

CHIOU TJ, CHU ST, TZENG WF, HUANG YC, LIAO CJ: Arsenic Trioxide Impairs Spermatogenesis via Reducing Gene Expression Levels in Testosterone Synthesis Pathway. Chem Res Toxicol 21: 1562-1569, 2008. https://doi.org/10.1021/tx700366x

DE ARAUJO RAMOS AT, DIAMANTE MAS, DE ALMEIDA LAMAS C, DOLDER H, DE SOUZA PREDES F: Morphological and morphometrical changes on adult Wistar rat testis caused by chronic sodium arsenite exposure. Environ Sci Pollut Res Int 24: 27905-27912, 2017. https://doi.org/10.1007/s11356-017-0200-2 
DA SILVA RF, BORGES CDS, DE ALMEIDA LAMAS C, CAGNON VHA, DE GRAVA KEMPINAS W: Arsenic trioxide exposure impairs testicular morphology in adult male mice and consequent fetus viability. $\mathrm{J}$ Toxicol Environ Health A: 1-14, 2017. https://doi.org/10.1080/15287394.2017.1376405

EIYAMA A, OKAMOTO K: PINK1/Parkin-mediated mitophagy in mammalian cells. Curr Opin Cell Biol 33: 95-101, 2015. https://doi.org/10.1016/j.ceb.2015.01.002

GUVVALA PR, SELLAPPAN S, PARAMESWARAIAH RJ: Impact of arsenic (V) on testicular oxidative stress and sperm functional attributes in Swiss albino mice. Environ Sci Poult Res Int 23: 18200-18210, 2016. https://doi.org/10.1007/s11356-016-6870-3

HAMACHER-BRADY A, BRADY NR: Mitophagy programs: mechanisms and physiological implications of mitochondrial targeting by autophagy. Cell Mol Life Sci 73: 775-95, 2016. https://doi.org/10.1007/s00018$\underline{015-2087-8}$

HANA XX, JIANGA YP, LIUB N: Protective effects of Astragalin on spermatogenesis in streptozotocininduced diabetes in male mice by improving antioxidant activity and inhibiting inflammation. Biomed Pharmacother 110:561-570, 2019. https://doi.org/10.1016/j.biopha.2018.12.012

HORIBE A, EID N, ITO Y, OTSUKI Y, KONDO Y: Ethanol-induced autophagy in sertoli cells is specifically marked at androgen-dependent stages of the spermatogenic cycle: potential mechanisms and implications. Int J Mol Sci 20: 184, 2019. https://doi.org/10.3390/ijms20010184

HOWARD CV, REED MG: Unbiased Stereology: Three-dimensional measurement in microscopy (2nd ed.). Garland Science/BIOS Scientific, Abingdon, UK. 2005.

HUANG Q, LUO L, ALAMDAR A, ZHANG J, LIU L, TIAN M, EQANI SA, SHEN H: Integrated proteomics and metabolomics analysis of rat testis: Mechanism of arsenic-induced male reproductive toxicity. Sci Rep 6: 32518, 2016. https://doi.org/10.1038/srep32518

JIANG YP, YANG JM, YE RJ, LIU N, ZHANG WJ, MA L, ZHENG P, NIU JG, LIU P, YU JQ: Protective effects of betaine on diabetic induced disruption of the male mice blood-testis barrier by regulating oxidative stressmediated p38 MAPK pathways. Biomed Pharmacother 120:109474, 2019. https://doi.org/10.1016/j.biopha.2019.109474

KAPLAN S, ODACI E, ÖNGER ME, ASLAN H, ÜNAL B: The dissector counting technique. Neurol Quantol 10: 44-53, 2012. https://doi.org/10.14704/nq.2012.10.1.425

KOENTJORO B, PARK JS, SUE CM: Nix restores mitophagy and mitochondrial function to protect against PINK1/Parkin-related Parkinson's disease. Sci Reprod 10: 44373, 2017. https://doi.org/10.1038/srep44373

KUMAR V, CRLSON JE, OHGI KA, EDWARDS TA, ROSE DW, ESCALANTE CR, ROSENFELD MG, AGGARWAL AK: Transcription corepressor CtBP is an $\mathrm{NAD}^{(+)}$-regulated dehydrogenase. Mol Cell 10 : 857-869, 2002. https://doi.org/10.1016/S1097-2765(02)00650-0

MANTHEYA KC, RODRIGUEZ-MELENDEZA R, HOIA JT, ZEMPLENI J: Riboflavin deficiency causes protein and DNA damage in HepG2 cells, triggering arrest in G1 phase of the cell cycle. J Nutr Biochem 17: 250-256, 2006. https://doi.org/10.1016/i.jnutbio.2005.05.004

MARSHALL RS, VIERSTRA RD: Autophagy: the master of bulk and selective recycling. Annu Rev Plant Biol 69: 173-208, 2018. https://doi.org/10.1146/annurev-arplant-042817-040606

MAYHEW TM, GUNDERSEN HJG: If you assume, you can make an ass out of $u$ and me: a decade of the dissector for stereological counting of particles in 3D space. J Anatomy 188: 1-15, 1996.

MCBRIDE JA, COWARD RM: Recovery of spermatogenesis following testosterone replacement therapy or anabolicandrogenic steroid use. Asian J Androl 18: 373-380, 2016. https://doi.org/10.4103/1008-682X.173938

OH RC, BROWN DL: Vitamin B12 deficiency. Am Fam Physician 67: 979-986, 2003.

OLFATI A, MOGHADDAM G, BARADARAN B: FSH and estradiol benzoate administration recover spermatogenesis and sexual hormone levels in a busulfan-injured rat model. Com Clin Pathol 1-7, 2019. https://doi.org/10.1007/s00580-019-03029-3

OLFATI A, MOGHADDAM G, RAFAT-KHAFAR K, MOJTAHEDIN A, ABDOLAHZADEH A: Role of folliclestimulating hormone and estradiol benzoate in recovering spermatogenesis in tamoxifen-injured rats. Asian Pac J Reprod 7: 248-253, 2018. https://doi.org/10.4103/2305-0500.246342 
RAO X, HUANG X, ZHOU Z, LIN X: An improvement of the $2^{\wedge}$ (-delta delta CT) method for quantitative real-time polymerase chain reaction data analysis. Biostat Bioinforma Biomath 3: 71-85, 2013.

REDDY UA, PRABHAKAR PV, MAHBOOB M: Biomarkers of oxidative stress for in vivo assessment of toxicological effects of iron oxide nanoparticles. Saudi J Biol Sci 24: 1172-1180, 2017. https://doi.org/10.1016/j.sjbs.2015.09.029

RIVLIN RS: Riboflavin. BA BOWMAN, RM RUSSELL (eds). In: Present knowledge in nutrition. Washington (DC)7 ILSI Press. 191-198, 2001.

SAHA R, ROYCHOUDHURY S, KAR K, VARGHESE AC, NANDI P, SHARMA GD, FORMICKI G, SLAMA P, KOLESAROVA A: Coenzyme Q10 ameliorates cadmium induced reproductive toxicity in male rats. Physiol Res 68: 141-145, 2019. https://doi.org/10.33549/physiolres.934000.

SAKHAEE E, EMADI L, ABSHENAS J, KHEIRANDISH R, AZARI O, AMIRI E: Evaluation of epididymal sperm quality following experimentally induced copper poisoning in male rats. Andrologia 44 (Suppl 1): 110-116, 2012. https://doi.org/10.1111/j.1439-0272.2010.01147.x

SARKAR S, HAZRA J, UPADHYAY SN, SINGH RK, ROY CHOWDHURY A: Arsenic induced toxicity on testicular tissue of mice. Indian J Physiol Pharmacol 52: 84-90, 2008.

SCHNEIDER JL, CUERVO AM: Autophagy and human disease: emerging themes. Curr Opin Genet Dev 26: 16-23, 2014. https://doi.org/10.1016/j.gde.2014.04.003

SHAO YZ, ZHAO HJ, WANG Y, LIU JJ, LI JL, LUO LY, XING MW: The apoptosis in arsenic-induced oxidative stress is associated with autophagy in the testis tissues of chicken. Poult Sci 1: 97: 3248-3257, 2018. https://doi.org/10.3382/ps/pey156

SOUZA AC, MARCHESI SC, FERRAZ RP, LIMA GD, DE OLIVEIRA JA, MACHADO-NEVES M: Effects of sodium arsenate and arsenite on male reproductive functions in Wistar rats. J Toxicol Environ Health A 79: 274-286, 2016. https://doi.org/10.1080/15287394.2016.1150926

SUN X, LI J, ZHAO H, WANG Y, LIU J, SHAO Y, XUE Y, XING M: Synergistic effect of copper and arsenic upon oxidative stress, inflammation and autophagy alterations in brain tissues of Gallus gallus. J Inorg Biochem 178: 54-62, 2018. https://doi.org/10.1016/j.jinorgbio.2017.10.006

TABARRAEI H, HASSANB J, PARVIZIA MR, GOLSHAHIC H, KESHAVARZ-TARIKHI H: Evaluation of the acute and sub-acute toxicity of the black caraway seed essential oil in Wistar rats. Toxicol Reports 6: 869-874, 2019. https://doi.org/10.1016/j.toxrep.2019.08.010

TAKAHASHI K, KITAOKA Y, MATSUNAGA Y, HATTA H: Effects of lactate administration on mitochondrial enzyme activity and monocarboxylate transporters in mouse skeletal muscle. Physiol Rep 7: e14224, 2019. https://doi.org/10.14814/phy2.14224

UNNIKRISHNAN D, DUTCHER JP, GARL S, VARSHNEYA N, LUCARIELLO R, WIERNIK PH: Cardiac monitoring of patients receiving arsenic trioxide therapy. Br J Haematol 124: 610-617, 2004. https://doi.org/10.1111/j.1365-2141.2003.04817.x

WANG P, FAN F, LI X, SUN X, MA L, WU J, SHEN C, ZHU H, DONG Z, WANG C, ZHANG S, ZHAO X, MA X, ZOU Y, HU K, SUN A, GE J: Riboflavin attenuates myocardial injury via LSD1-mediated crosstalk between phospholipid metabolism and histone methylation in mice with experimental myocardial infarction. J Mol Cell Cardiol 115: 115-129, 2018. https://doi.org/10.1016/j.yjmcc.2018.01.006

ZHENG Y, FLANAGAN SV: The case for universal screening of private well water quality in the U.S. and testing requirements to achieve it: Evidence from Arsenic. Environ Health Perspect 125: 085002, 2017. https://doi.org/10.1289/EHP629

ZHOUA T, CHANGB L, LUOA Y, ZHOUB Y, ZHANG JJ: Mst1 inhibition attenuates non-alcoholic fatty liver disease via reversing Parkin-related mitophagy. Redox Biol 21: 101120, 2019. https://doi.org/10.1016/j.redox.2019.101120 